\title{
THE ANALYSIS OF ENGLISH LANGUAGE EDUCATION STUDENTS' TEACHING SKILLS DURING MICROTEACHING: PRODUCT-PROCESS APPROACH IN TEACHING GRAMMAR
}

\author{
Atalya Agustin \\ atalya.agustin@uph.edu \\ English Language Education \\ Faculty of Education, Universitas Pelita Harapan
}

\begin{abstract}
Teaching grammar within the context of Second Language Acquisition (SLA) needs both product and process approaches. Microteaching is one of the techniques to prepare students teachers to improve their skills in this area. One of the microteaching lessons in English Language Education Department, Teachers College Universitas Pelita Harapan, is called Planning, Strategy, Assessment, and Learning (PSAL) Grammar. In this class, students are exposed with the nature, principles, and strategy of teaching and learning grammar. Students are planning lessons related to teaching grammar in various grades as well as developing teaching and learning material and instrument for language assessment. Students then put them into practice in the classroom individually. Discussion on the students 'performances will be conducted after the microteaching session. This research aims to analyze students' skills in teaching grammar in microteaching class as well as the discussing the strength and challenges arise. The type of the research is a qualitative case study research. The data collection techniques being used are observation, reflective journal, and Focus Group Discussion (FGD). Moreover, the technique of analyzing the data was Miles and Huberman concept of data reduction, data presentation, and conclusion drawing. The results of this research will be presented in a descriptive-narrative manner by describing and discussing students' skills in teaching grammar in conducting process-product approach.
\end{abstract}

Key Words: teaching and learning skills, microteaching, product-process approach, grammar.

\section{Article Info}

Received date: 15 Agustus 2017 Revised date: 26 Agustus $2017 \quad$ Accepted date: 18 September 2017

\section{INTRODUCTION}

An essential part of becoming a teacher is to teach in a holistic approach. It means that the teacher himself/herself understand the nature and purpose of the material and also the effective way of teaching it as well as the nature of teacher, students, and how to manage them to be able to achieve the purpose of education. According to Undang-Undang no. 14, 2005 about teacher and lecturer in chapter VI section 3, teachers must have several competencies such as pedagogical competence, personality competence, professional competence and social competence. These competencies are needed to help teachers developing well planned lesson plan, teaching, and managing the students in class.

As a very important situated and designed teaching practice, microteaching will enhance student teachers' ability to teach and continuously renew the existing skills. In English Language Education Department Universitas Pelita Harapan (UPH), one of the microteaching lessons is Planning, Strategy, Assessment, and Learning (PSAL) Grammar. In this class, students will plan a 
The Analysis Of English Language Education Students' Teaching Skills During Microteaching: Product-Process Approach In Teaching Grammar (Atalya Agustin)

lesson related to teaching grammar then practice it among peers. Feedback from peers and lecturer are both very important as well as teachers' own evaluation.

Students teacher in FIP UPH are prepared to be ready in teaching grammar within the context of ESL/EFL. Obviously, they need strategy to cope with the challenges such as fluency and accuracy in using grammar. One of the approaches which could help the teachers to teach holistically in grammar as well as to prepare the students to have their own rationality and autonomy of using grammar is product-process approach. By doing this, what the students have learned could be meaningful and last longer. This is aligned with the definition of product and process approach by Palpanadan, Rahim, and Ismail (2014) which said that process approach focuses more on the process in achieving the goal rather that the end product like in the product approach. Nonetheless, if both approaches are combined, teaching and learning will be more effective.

\section{LITERATURE}

Grammar, according to Thornbury (2001), is a kind of natural process which will develop in its own harmony and in mysterious way. Teacher needs to understand it and provide such an important yet stimulating condition. It is very challenging to teach grammar in English class. According to Al-Mekhlafi (2011), there are many kinds of struggles met by students and teacher regarding to grammar instruction in an ESL/EFL context. Teacher needs to understand the nature and purpose of teaching grammar as well as the techniques for the best practices together with appropriate and convenient assessment.

In teaching grammar, the skills have to be improved in order to cope with the challenges. When teachers start a class, they will use skills in order to attract students' attention, motivate them and develop bond between students and teacher. These skills include the strategy to review previous class's material and connect it with the upcoming class, give instruction to the students in different pattern, and use aids. When teachers end the class, they will draw conclusions and evaluations. This final session in teaching includes assignments based on the teaching and learning process, questions to check students' understanding, as well as conclusion.

Besides equipping themselves with strong foundation related to nature and purpose of grammar and some teaching skills, it is important to choose the suitable and comprehensive approach. Palpanadan, Rahim, and Ismail (2014) explains about product-process approach. Product approach asks students to produce language (essay) based on certain example. It is more on form rather than content. Meanwhile, Process approach encourages students to experience writing process which focus more on cognitive process (content) rather than form. Both approaches are needed when it comes to holistic approach to language teaching and learning. If product-process approach, however, is being used complementary, it would benefit the students with the significant advantages from both approaches.

\section{METHOD}

This research is conducted in one of microteaching classes in 5th semester in Faculty of Education UPH. This research is a qualitative case study research which has 1 student who major English Language Education as the subject. Based on Bassey (1999), this research is a story-telling type of case study which will explain the phenomena to be able to contribute in theoretical framework. The subjects were chosen using purposive sampling. Purposive sampling, according to Mulyana (2010) is choosing samples purposively where researchers can find samples who are willing to give data. Moreover, there is no standard on how many samples should be used in this sampling. The student being chosen is the one who conducted product-process approach in the microteaching.

Data collection was held in a natural setting using observation sheets. It was conducted once in the microteaching class. Afterevery session of teaching, the student teachers wrote the reflective journal. This journal would also be one of the instruments. Researchers also conducted Focus Group Discussion (FGD) to get in-depth analysis towards the observation and reflection. This discussion is to help the students to be aware of what skills they have developed well and what skills they have to improve.

Researchers analyzed the data by examining all the data collected in observation, reflective journal, and Focus Group Discussion. There are three steps of qualitative data analysis which are data reduction, data presentation and conclusion drawing. Researchers reduce the data using microteaching 
class' rubrics. Data presentation is in form of descriptive narrative. Finally, the conclusion is drawn through the triangulation betweenthe data from observation, reflection, and FGD

\section{FINDINGS AND DISCUSSION}

There are 1 student who became the subject of this research which are Student Teacher E (STE)). She conducted process-product approach in the classroom to teach grammar. Based on the data obtained from observation, reflection, and FGD, the findings are as follows:

The first basic teaching skill assessed in the microteaching rubrics is the ability to open the class. STE opened the class by asking how the students are doing and letting one of the students to lead in a prayer.In this opening session, teacher attracted students' attention by using several ways, such as explaining the agenda that they were going through that day, displaying the agenda on the screen and using interesting audio-visual aid. STE also played her tones when she explained so that the students would be more attracted and at the same time feel more relaxed. The teacher mentioned the word "menu" so that the students would get interested and curious because of the unusual use of this term. The students were all interested and focused on the screen to see what was coming.

STE: "Let's take a look at today's menu (while displaying the agenda on screen).

STE gave some instructions in the classroom.

First, she mentioned the rules that the students should obey during the teaching and learning process related to behavior and attitude of the students. Second, teachers asked the student to watch and listen carefully when teacher played something on the screen or when the teacher explained the material. Moreover, STE asked the students to recall the material of the previous class in order to review what they have learned before and connected the lesson they were about to experience.

One thing that really helped the student to make sense of their learning was the animation picture of the material being displayed and followed with teacher's instruction to guess the meaning of the video. By doing this, the teacher encouraged the students to think critically about the material they were about to learn and had learned. In this moment, bonding between students and teachers took place. It was shown by the communication between both sides. Teachers gave instruction and the students responded well. Overall, she really thought about the strategies to open the session very well and she really took it seriously.

In her reflection, she mentioned that she thought the session went well even though there were some weaknesses. She felt she could be more alive in carrying out herself so that the students would feel comfortable and closer to her. She also wanted her best to pay attention to details in this microteaching so that the students would find the teaching and learning meaningful and contextual with their lives.

When the Focus Group Discussion (FGD) took place, the forum gave the suggestion related to her voice which could have been louder. Her tones could have also been more playful and friendly since she was teaching $6^{\text {th }}$ graders. However, the way she opened the class has successfully attracted students' attention and at the same time prepared to the lesson. To respond towards the comments, STE said that she has to improve her voice and tone variation in the next microteaching or in the next teaching practicum. Below was the comment given by the forum:

Friend $X:$ "Your voice needs to be louder and..um..more cheerful."

Friend Y:" The AVA was interesting and could make the students curious."

By comparing the data from three instruments, it is shown that she has worked well in doing the opening that covers the ability to attract students' attention, use aids, vary interaction pattern, motivate, create the bond between student and teacher, give instruction, review the previous class, and connect the previous class with the ongoing class. She was well prepared and paid attention to details. She really planned the opening session so that it would draw students' attention and curiosity. Regarding her weaknesses, in the future she will develop more and have more practice.

The second aspect to be assessed was the skills of asking and answering questions. This skill was assessed from the beginning of the session until the end. It covered the ability to encourage students to ask, to ask questions which were in line with the material, to ask questions which promoted students' critical thinking as well as maximize students' ability, and to answer the students' questions appropriately.

STE conducted question and answer session since the beginning of the class. She asked the students regarding the previous lesson they had. This type of questions tried to check students' prior 
The Analysis Of English Language Education Students' Teaching Skills During Microteaching: Product-Process Approach In Teaching Grammar (Atalya Agustin)

knowledge. Another question was to guide the students to guess the meaning of the video being played. This video would prepare the students for the lesson. Below was the question:

STE: "D o you know what is it about?"

STE:" D o you know how to use "like" and "prefer" before?"

During the whilst-teaching period, STE also raised some questions as well as gave some answers to students' questions. She checked students' understanding and asked their opinion towards some topics. Some students asked some question related to the rules and procedures of their class activities and the meaning of them. STE managed to answer them appropriately.

STE: "What do you think of........?"

Based on her reflection, she tried so hard to raise questions which had something to do with the material. Yet, she still felt that her effort was not enough. Her questions were okay but not specifically addressing critical thinking. She believes if she did it in the higher level, she could perform well. Moreover, she believed that she could answer the questions from the students well. Those questions were primarily technical. They were related to the rules and procedures of the class activities. She expected more fundamental questions.

From the FGD with the other students, the forum appreciated the way she asked questions. Even though the students were only grade 6 , but she tried to give questions to promote critical thinking. The questions were simple, to the point, and related to the material. The forum believed that teacher didn't need difficult questions to check students' understanding and encourage them to think critically. The forum also thought that the answer given by the teacher was appropriate. But, teacher needed to develop the ability to encourage the student to ask more fundamental questions.

Based on the data from observation, reflection, and the FGD, it can be taken into account that the teacher asked the questions which were in line with the material. The teacher also asked questions to trigger the students to think critically. Sophisticated questions were not needed in this stage because of the level of the students. Simple and to-the-point questions could still encourage students to think critically. The teacher also had answered the questions raised by students properly. However, the teacher still needed to develop her ability to encourage the students to ask. Strategies or certain techniques should be used to have the students try to ask. Asking question is important because from the question we could also check students' understanding.

The third and fourth aspects being assessed are the skill to master and explain content knowledge and the skill to use approach, method or strategy. These aspects would be discussed together in this part because both of them are interrelated. STE mastered the content which was about expressing opinion using like, prefer, and would rather. She also presented the material systematically through several activities such as games, listening activity, and group work. It seemed that she also followed the teaching plan well and had manages the time accordingly.

STE use process-product approach in her microteaching. This approach facilitates the students to not only focus on the end product but also the process of understanding the material or the cognitive structure. Since the beginning of the class, precisely before she explained the aim of the lesson and the material, she asked the students to watch the animation about "like", "prefer", and "would like". She then asked the students to guess what topic they would learn. By doing this, STE gave the opportunity to the students to analyze and make sense of what they had ever experienced. It was easier then to guess what to learn and to make meaning of it. After playing the animation, teachers discussed the material and asked them to explain what they already knew and wanted to know. These chronological steps were actually the way STE built the cognitive structure of the students in order to be ready for the next activities. When explaining the lesson, STE gave sample sentences and asked the students to restate the sentences. Students were asked to create their own sentences as the next guided activity. Finally, to strengthen the understanding, STE conducted games, listening session, and group work activity.

Based on her reflection, STE said that she was happy with how the result turned out to be. The students seemed to follow the instruction well and could understand the aim of the lesson. She realized that even though it was not really an actual class, but it could portray the challenges of the real class. It was actually a great idea to start the class with animation and developed activities out of it. The combination between teacher's guided activities and independent activities could really help the students 
FGD did show the same result with the observation and reflection. The forum mentioned that STE master the content well, presented it systematically and followed the teaching plan. The way STE has arranged the class also worked very well with the characteristic of the material. She worked with the students' understanding first and then asked them to create something as the way to check their understanding.

Based on the three ways of data collection, it can be concluded that STE mastered the content well, delivered it systematically and had used the right approach for her material. The way she structured the lesson in a process and product orientation has helped the students to learn.

The last skill was the skill to make conclusion and evaluation and closing skills. After all the students finished with the activity, STE asked them to review the material together. This was to check students' understanding and also to draw conclusion from today's activity. STE reflected that she could evaluate students' understanding and draw conclusion well. FGD also discussed he same thing which was teacher's sufficient ability to check students' understanding and conclude the lesson.

From the overall result of the study, it is shown that the student teacher conducted the product-process approach well so that it can help the students to structure their cognitive as well as produce expected result. This result or product could help the teacher to make sure whether the objectives of the teaching and learning could be achieved well. This is aligned with the theory proposed by that Palpanadan, Rahim, and Ismail (2014) that it is very important to plan the language teaching and learning process in the classroom by embracing as well as modifying some important aspects from both product and process approach. Process approach has its own strength in developing firm concept and maintaining continuous learning progress. Meanwhile, product approach is able to focus on the correct language form. Both of them could help the students especially when they have variety of learning styles.

Another result in this study shows that through various activities in grammar class such as games, listening section, and group work as well as the interesting audio visual aids, teacher and student could create more relaxed atmosphere in the classroom. This could eliminate the anxiety and difficulties in teaching and learning grammar for both teacher and student. This is aligned with the statement by Al-Mekhlafi (2011) who said that recognizing difficulties and becoming concerned with them could help teacher solve the problems and promote best practices in the classroom.

Student teacher did the microteaching well even though there were still some limitation in the basic teaching skills. However, this practice is very important in the senior year as the student teacher to improve new skills as well as upgrading the old ones even though microteaching is not the real classroom (Duminy, MacLarty, and Massdorp, 1992). The opportunities and challenges happened in this situated context might at least give the teacher a sneak peek before the whole performance takes place.

\section{CONCLUSION}

Student teachers were ableperform some skills related basic teaching skills such as to open the lesson, asking critical questions based on the material. Moreover, teacher also could conduct the lesson holistically and aim at the objectives through product and process approach in teaching grammar. Finally, the student teachers closed the lesson by checking understanding, drawing conclusion, and giving assignment or instruction for the next meeting. Through the combined approaches, teacher could help the students to structure their cognitive by conducting the process approach and check their further understanding in language use by conducting the product approach.

\section{REFERENCES}

Al-Mekhlafi. 2011. Difficulties in Teaching and Learning Grammar in an EFL Context. International Journal of Instruction. 4 (2): 69-92.

Bassey, Michael. 1999. Case Study Research in Educational Settings. Buckingham: Open University Press. 
The Analysis Of English Language Education Students' Teaching Skills During Microteaching: Product-Process Approach In Teaching Grammar (Atalya Agustin)

Duminy, P.A, MacLarty,. A.H, \& Massdorp, N. 1992. Teaching Practice. Cape Town: MaskewMiller Longman

Kyriacou, C. 2007. Essential Teaching Skills, 3rd ed. Cheltenham: Nelson Thornes Limited.

Mulyana, D. 2010. Metodologi Penelitian Kualitatif: Paradigma Baru Ilmu Komunikasi dan Ilmu Sosial Lainnya. Bandung: PT. Remaja Rosdakarya.

Palpanadan, Thulasi, Rahim, Abdul bin Salam, and Ismail, Fauziah. 2014. Comparative Analysis of Process Versus Product Approach of Teaching Writing in Malaysian Schools: Review of Literature. Middle-East Journal of Scientific Research 22 (6): 789-795.

Thornbury, Scott. 2001. Uncovering Grammar. Oxford: Macmillan Heinemann.

\section{Author"sProfile}

Atalya Agustin was born in Salatiga, Central Java, 20 ${ }^{\text {th }}$ August 1987. Her Undergraduate Degree is from Satya Wacana Christian University Salatiga majoring English Language Education (2009). Meanwhile, her Master Degree is from Universitas Negeri Semarang majoring Indonesian Language Education for Primary Education (2012). She is now a lecturer and head of department in English Language Education, Teachers College, Universitas Pelita Harapan, Tangerang, Banten, Indonesia (2013-present). Her research interests are within the area of linguistics as well as Indonesian and English language education. 